\title{
Implementasi Pisanc Chiper Untuk Autentikasi Voice Chat
}

\author{
Muhammad Fajar Rizky, Muhammad Syahrizal, Soeb Aripin \\ Fakultas Ilmu Komputer dan Teknologi Informasi, Prodi Teknik Informatika, Universitas Budi Darma, Medan, Indonesia \\ Email: ${ }^{1}$ mhd.frizky27@gmail.com, ${ }^{2} \mathrm{msyahrizal} 86 @$ gmail.com \\ Submitted: 26/07/2021; Accepted: 22/08/2021; Published: 31/08/2021
}

\begin{abstract}
Abstrak-Dalam melakukan pengamanan pesan suara informasi yang dikirimkan melalui jaringan internet tersebut harus diautentikasi keasliannya, isi datanya, waktu pengiriman, dan lain-lain. Untuk mencegah terjadinya manipulasi data oleh pihakpihak yang tidak bertanggung jawab maka, terciptanya suatu kebocoran data yang berdampak negatif. Terjadinya kebocoran data yang kini masih kurang diwaspadai oleh kebanyakan pengguna. Hal ini bisa saja terjadi dikarenakan kurangnya keamanan pesan itu sendiri yang mengakibatkan masalah yang timbul dan juga kerugian oleh pihak otoriter tertentu. Solusi dalam pengamanan pesan suara tersebut menggunakan teknik kriptografi modern yang telah di kombinasikan dari pengkodean enkoding NRZI dan jaringan feistel oleh Pisanc Cipher, merupakan cara untuk menjaga keaslian dan keakuratan data atau autentikasi pada pesan suara. Berguna untuk mencari karekteristik enkripsi yang baik yaitu kebingungan dan difusi. Sehingga didapatkan keamanan dengan tingkat yang lebih tinggi. Dengan menggunakan metode Pisanc Cipher untuk mengamankan pesan suara, dapat menghasilkan suatau keamanan dan mengautentikasikan suatu data untuk mencegah terjadinya kebocoran data. Selain itu manfaat lain dari pengunaan metode Pisanc Cipher dapat menjaga suatu keaslian pesan suara.
\end{abstract}

Kata Kunci: Pengamanan; Pesan Suara; Kriptografi; Pisanc Cipher

Abstract-In securing voice messages, information sent through the internet network must be authenticated for its authenticity, data content, delivery time, and so on. To prevent data manipulation by irresponsible parties, the creation of a data leak that has a negative impact. The occurrence of data leaks that most users are still not aware of. This can happen due to the lack of security of the message itself which results in problems that arise and also losses by certain authoritarian parties. The solution in securing voice messages using modern cryptographic techniques that have been combined with NRZI encoding and the Feistel network by Pisanc Cipher, is a way to maintain the authenticity and accuracy of data or authentication in voice messages. It is useful to look for the characteristics of good encryption, namely confusion and diffusion. This results in a higher level of security. By using the Pisanc Cipher method to secure voice messages, it can generate security and authenticate data to prevent data leakage. In addition, another benefit of using the Pisanc Cipher method is to maintain the authenticity of voice messages.

Keywords: Security; Voicemail; Cryptography; Pisanc Cipher

\section{PENDAHULUAN}

Perkembanganteknologi dan informasi kini semakin memudahkan manusia dalam menyelesaikan pekerjaannya dengan cepat dan praktis. Dunia teknologi dan informasi yang kini jugabanyak di butuhkan dalam bidang militer, perkantoran juga personaldan lain sebagainya yangbisa dirasakan manfaatnya. Seperti halnya teknologi informasi yang berbasis pesan suara merupakan teknologi yang sedang berkembang pesat saat ini, dan juga memepengaruhi kemajuan dalam aspek kehidupan yang didukung oleh kemajuan teknologi tersebut untuk memepermudah mengakses data atau informasi. Dari manfaat yang dihasilkan oleh pesan suara, kini manusia lebih mudah terhubung dan berkomunikasi dengan cepat. Akan tetapi harus kita waspadai juga apabila pesan yang kita anggap penting bisa diketahui oleh pihak-pihak yang tidak bertanggung jawab yang akan menimbulkan kerugian bagi pemlilik dan pengguna pesan suara tersebut.

Terjadinya percakapan di dalam sebuah aplikasi menggunakan layanan pesan suara dimaksud dengan komunikasi. Komukasai merupakan proses pertukaran informasi yang dimana hasil dari komunikasi tersebut menghasilkan data atau informasi.Pesan suara yang terhubung dengan jaringan internet adalah (VoIp) Voice Over Internet Protocolyaitu pesan suara yang menggunakan suatu aplikasi yang menggunakan jaringan internet dimana pesan suara tersebut menggunakan suatu jaringan yang harus terhubung ke internet. Dalam hal ini harus kita perhatikan dengan cermat dikarenakan pesan yang dikirim dan yang dierima harus terhubung ke suatu jaringan internet. Pesan suara tersebutdiubah menjadi kode digital dan dialirkan melalui jaringan yang mengirimkan paketpaket data, dan bukan melalui sirkuit analog telepon biasa.

Informasi yang dikirimkan melalui jaringan internet tersebut harus diautentikasi keasliannya, isi datanya, waktu pengiriman, dan lain-lain. Untuk mencegah terjadinya manipulasi data oleh pihak-pihak yang tidak bertanggung jawab maka, terciptanya suatu kebocoran data yang berdampak negatif. Misalnya pada saat pengiriman pesan ke pihak tertentu ternyata isi dari pesan tersebut sudah tidak asli lagi ataupun sudah diketahui isi datanya dengan kata lain sudah dalam pengupingan atau pengawasan oleh orang ketiga. Terjadinya kebocoran data yang kini masih kurang diwaspadai oleh kebanyakan pengguna. Hal ini bisa saja terjadi dikarenakan kurangnya keamanan pesan itu sendiri yang mengakibatkan masalah yang timbul dan juga kerugian oleh pihak otoriter tertentu.

Konsep kriptografi klasik lebih rentan untuk di pecahkan oleh cryptanalysis untuk diambil data maupun informasinya. Berbeda dengan kriptografi modern yang dimana menggunakan pengamanan dengan tingkat kerumitan yang lebih tinggi sehingga dapat menjaga keaslian dan kerahasiaan pesan dengan baik. Maka dari itu voice chat yang diekripsi lebih susah untuk dipecahkan oleh cryptanalysis. Oleh karena itu lebih aman apabila menjaga keaslian ataumengautentikasivoice chat dengan menggunakan teknik kriptografi modern yang telah di 
kombinasikan dari pengkodean enkoding NRZI dan jaringan feistel oleh Pisanc Chiper. Pisanc Chiper merupakancara untuk menjaga keaslian dan keakuratan data atau autentikasi pada pesan suara. Disini penulis menggunakan algoritma Pisanc Chiper yang dimana algoritma tersebut menggunakan kombinasi anatara NRZI dan juga jaringan feistel berguna untuk mencari karekteristik enkripsi yang baik yaitu kebingungan dan difusi.Sehingga didapatkan keamanan dengan tingkat yang lebih tingi.

\section{METODOLOGI PENELITIAN}

\subsection{Kriptografi}

Kriptograf (Cryptography) berasal dari bahasa Yunani, terdiri dari dua suku kata yaitu kripto dan graphia. Kripto artinya menyembunyikan, sedangkan graphia artinya tulisan. Kriptografi adalah ilmu yang mempelajari teknikteknik matematika yang berhubungan dengan aspek keamanan informasi, seperti kerahasian data, keabsahan data, integritas data, serta autentikasi data. Tetapi tidak semua aspek keamanan informasi dapat diselesaikan dengan kriptografi dikarenakan setiap software pasti memiliki kelebihan dan kelemahannya masing-masing [2].

\subsection{Algoritma Pisanc Chiper}

Algoritma PISANC adalah algoritma yang mencari karakteristik enkripsi yang baik yaitu kebingunggan, difusi, dan jaringan feistel. Karakteristik-karakteristik ini dipenuhi dengan pengokodean NRZI yang biasa ditemukan dilapisan OSI dan ekstensi lapisan feistel yang disebut triple feistel. Gabungan kedua ide dasar ini sudah dapat memenuhi karakteristik kebinggungan. Sehingga proses enkripsi tidak mudah di kenali oleh pihak yang tidak bertanggug jawab.

Enkripsi PISANC secara keseluruhan bekerja dengan terlebih dahulu mengenkripsi plainvoice dengan cara menggunakan enkoding NRZI dan kemudian diteruskan dengan mengenkripsi hasilnya dengan perputaran triple feistel. Sedangkan fungsi dari triple feistel disini bertujuan agar plainvoice yang telah di enkripsikan menjadi kode oleh NRZI menjadi berhamburan dan menyebabkan kebingungan dan difusi apabila cryptanalis ingin memecahkan dan membuka kunci tersebut. Enkripsi PISANC menggunakan kunci yang sama mulai dari 1 bit hingga $1 \mathrm{~GB}$. Yang dimana pengkodean NRZI hanya membutuhkan satu kunci dengan perlulangan hingga 5 kali putaran sedangkan triple feistel membutuhkan kunci sebanyak dua kali putaran [5].

\subsection{Voice Chat}

Cara bahasa pengertian chatting adalah suatu pesan instan dalam teknologi jaringan komputer untuk mengirimkan informasi ke pengguna lain yang terhubung melalui koneksi internet. Saat ini, istilah chatting tidak hanya ditemukan pada pengguna email messenger saja, karena sudah banyak aplikasi chatting yang tersedia untuk pengguna smartphone. Voice Chat merupakan suatu program di Internet untuk berkomunikasi langsung sesama pengguna internet yang sedang online / yang sedang sama-sama menggunakan Internet. Komunikasi ini dapat berupa teks (text chat) ataupun suara (voice chat). Atau definisi chatting adalah suatu pesan instant ataupun instant messaging di sebuah teknologi jaringan komputer yang mengijinkan pemakainya untuk mengirimkan pesan ke pengguna lain yang tersambung dalam sebuah jaringan komputer ataupun internet [10].

\section{HASIL DAN PEMBAHASAN}

Sebuah pesan suara yang bersifat rahasia sangat rentang terhadap pengambilan data oleh pihak yang tidak berhak akan pesan tersebut demi keuntungan pribadinya ataupun kelompok. Kurangnya tingkat keamanan seperti penyandian dan penyembunyian terhadap pesan suara tersebut memudahkan pihak-pihak yang tidak tekait mengambilnya, terutama pada pesan suara yang belum disandikan.

Pesan suara rahasia yang belum disandikan jika berada ditangan yang salah, maka dengan sangat mudah dianalisa dan diambil datanya sehingga dapat merugikan pihak yang memiliki pesan suara rahasia tersebut. Maka hal ini dapat di minalisir dengan teknik kriptografi.

Berdasarkan rumusan masalah pada bab sebelumnya, masalah yang terjadi adalah bagaimana sebuah pesan suara yang belum disandikan dapat diamankan dan disandikan dengan teknik kriptografi. Teknik kriptografi akan mengacak data suara rahasia menjadi data yang tidak dapat dipahami ketika pihak yang tidak bertanggung jawab atau cryptanalis.

Maka metode yang digunakan dalam pembahasan ini adalah sebuah algoritma kriptografi Pisanc Cipher. Pisanc Cipher akan melakukan enkripsi terhadap pesan suara yang akan diamankan menggunakan pengkodean NRZI terdahulu dan proses selanjutnya menggunakan metode triple feistel. Dimana metode tersebut akan di enkripsikan oleh algoritma Pisanc Cipher.

\subsection{Penerapan Algoritma Pisanc Cipher}

Proses penerapan algoritma Pisanc Cipher adalah proses yang menggabungkan anatara NRZI dan triple feistel yang dimana dengan mengkodekan terdahulu suara dengan NRZI kemudian dilanjukan mengenkripsi hasil 
Journal of Computer System and Informatics (JoSYC)

Volume 2, No. 4, August 2021, Page 288-294

ISSN 2714-8912 (media online)

ISSN 2714-7150 (media cetak)

DOI 10.47065/josyc.v2i4.819

hasilnya dengan triple feistel. Triple fiestel melakukan putaran yang membuat kebingungannya dengan penerapan yang dimana melakukan putaran sampai 10 kali putaran. Maka yang akan dilakukan yaitu dari sebuah jenis pesan voice chat yang digunakan sebagai contoh untuk menerapkan algoritma Pisanc Cipher, penulis menggunakan jenis voice chat dari aplikasi

Proses selanjutnya adalah melakukan pengambilan nilai hexadecimal dari file voicechat yang akan digunakan, dalam hal ini penulis menggunakan aplikasi HxD. Berikut proses penggunaannya:

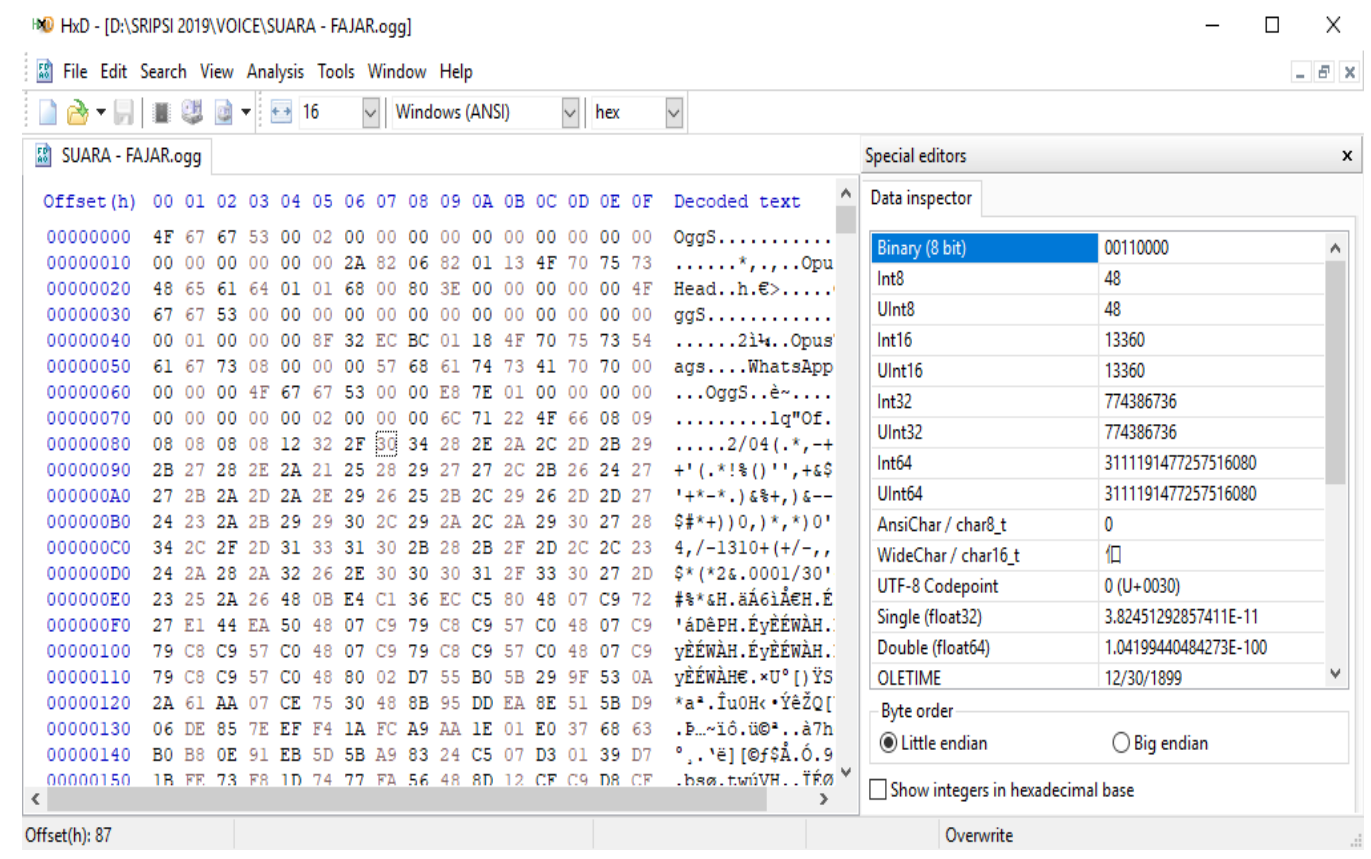

Gambar 1. Tampilan aplikasi HxD

Selanjutnya nilai yang akan digunakan untuk penerapan algoritma PISANC sebagai landasan dasar untuk mengenkripsi voicechat nantinya sebagai mana yang telah di tentukan nilai biner dari voicechat tersebut, penulis menggambil nilai sampel, sebagai berikut:

\section{[ 2B 2728 2E 2A 212528292727 2C 2B 26242727 2B 2A 2D 2A 2E 29 26]}

Maka Proses selanjutnya adalah menubah bilangan nilai bentuk biner kedalam betuk hexa desimal dengan menggunakan tabel ascii, aapun tabel ascii sebagai berikut;

\begin{tabular}{|c|c|c|c|c|}
\hline Binary & Oct & Dec & Hex & Glypt: \\
\hline 0100000 & 040 & 32 & 20 & $=$ \\
\hline 0100001 & 041 & 33 & 21 & , \\
\hline 0100010 & 042 & 34 & 22 & . \\
\hline 0100011 & 043 & 35 & 23 & $\#$ \\
\hline 0100100 & 044 & 36 & 24 & क \\
\hline 0100101 & 045 & 37 & 25 & $\infty$ \\
\hline 0100110 & 046 & 38 & 26 & \& \\
\hline 0100111 & 047 & 39 & 27 & \\
\hline 0101000 & 050 & 40 & 28 & $<$ \\
\hline 0101001 & 051 & 41 & 29 & \\
\hline 0101010 & 052 & 42 & $2 A$ & $\Rightarrow$ \\
\hline 0101011 & 053 & 43 & 28 & + \\
\hline 0101100 & 054 & 44 & 20 & . \\
\hline 0101101 & 055 & 45 & 20 & - \\
\hline 0101110 & 056 & 46 & 2E & \\
\hline 0101111 & 057 & 47 & $2 \mathrm{~F}$ & $s$ \\
\hline 0110000 & 06о & 48 & 30 & o \\
\hline 0110001 & 061 & 49 & 31 & 1 \\
\hline 0110010 & 062 & 50 & 32 & 2 \\
\hline 0110011 & 063 & 51 & 33 & 3 \\
\hline 0110100 & 064 & 52 & 34 & 4 \\
\hline 0110101 & 065 & 53 & 35 & 5 \\
\hline 0110110 & 066 & 54 & 36 & 6 \\
\hline 0110111 & 067 & 55 & 37 & 7 \\
\hline 0111000 & $0>0$ & 56 & 38 & 8 \\
\hline 0111001 & 071 & 57 & 39 & 9 \\
\hline 0111010 & 072 & 58 & $3 A$ & $:$ \\
\hline 0111011 & 073 & 59 & 38 & \\
\hline 0111100 & $0>4$ & 50 & 30 & $\alpha$ \\
\hline 0111101 & 075 & 61 & 30 & $=$ \\
\hline 0111110 & & 62 & उE & $>$ \\
\hline 0111111 & 77 & 63 & $3 F$ & $?$ \\
\hline
\end{tabular}

\begin{tabular}{|c|c|c|c|c|}
\hline Bimary & Oct & Dec & Hex & Glyph. \\
\hline 1000000 & 100 & 64 & 40 & $\infty$ \\
\hline 1000001 & 101 & 65 & 41 & A \\
\hline 1000010 & 102 & 66 & 42 & $\mathbf{B}$ \\
\hline 1000011 & 103 & 67 & 43 & $c$ \\
\hline 1000100 & 104 & 68 & 44 & $D$ \\
\hline 1000101 & 105 & 69 & 45 & E \\
\hline 1000110 & 106 & 70 & 46 & $F$ \\
\hline 1000111 & 107 & 71 & 47 & 0 \\
\hline 1001000 & 110 & 72 & 48 & $H$ \\
\hline 1001001 & 111 & 73 & 49 & \\
\hline 1001010 & 112 & 74 & $4 A$ & $J$ \\
\hline 1001011 & 113 & 75 & $4 B$ & k \\
\hline 1001100 & 114 & 76 & 40 & ᄂ \\
\hline 1001101 & 115 & 77 & 4D & $m$ \\
\hline 1001110 & 116 & 78 & $4 E$ & $N$ \\
\hline 1001111 & 117 & 79 & $4 F$ & 0 \\
\hline 1010000 & 120 & 80 & 50 & P \\
\hline 1010001 & 121 & 81 & 51 & $a$ \\
\hline 1010010 & 122 & 82 & 52 & $R$ \\
\hline 1010011 & 123 & 83 & 53 & $s$ \\
\hline 1010100 & 124 & 84 & 54 & $T$ \\
\hline 1010101 & 125 & 85 & 55 & $u$ \\
\hline 1010110 & 126 & 86 & 56 & $\checkmark$ \\
\hline 1010111 & 127 & 87 & 57 & $w$ \\
\hline 1011000 & 130 & 88 & 58 & $x$ \\
\hline 1011001 & 131 & 89 & 59 & $\gamma$ \\
\hline 1011010 & 132 & 90 & $5 A$ & $z$ \\
\hline 1011011 & 133 & 91 & 58 & I \\
\hline 1011100 & 134 & 92 & 50 & $x$ \\
\hline 1011101 & 135 & 93 & 50 & 1 \\
\hline 1011110 & 136 & 94 & SE & 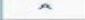 \\
\hline 1011111 & 137 & 95 & $5 \mathrm{~F}$ & \\
\hline
\end{tabular}

\begin{tabular}{|c|c|c|c|c|}
\hline Bimary & Oct & Dec & Hex & Gluph \\
\hline 1100000 & 140 & 96 & 60 & \\
\hline 1100001 & 141 & 97 & 61 & $\mathbf{a}$ \\
\hline 1100010 & 142 & 38 & 62 & b \\
\hline 1100011 & 143 & 99 & 63 & $c$ \\
\hline 1100100 & 144 & 100 & 64 & d \\
\hline 1100101 & 145 & 101 & 65 & $e$ \\
\hline 1100110 & 146 & 102 & 56 & $r$ \\
\hline 1100111 & 147 & 103 & 67 & 9 \\
\hline 1101000 & 150 & 104 & 68 & $n$ \\
\hline 1101001 & 151 & 105 & 69 & 1 \\
\hline 1101010 & 152 & 106 & EA & $\mathbf{j}$ \\
\hline 1101011 & 153 & 107 & 68 & k \\
\hline 1101100 & 154 & 108 & 60 & 1 \\
\hline 1101101 & 155 & 109 & 60 & $m$ \\
\hline 1101110 & 156 & 110 & GE & $n$ \\
\hline 1101111 & 157 & 111 & $6 \mathrm{~F}$ & 0 \\
\hline 1110000 & 160 & 112 & 70 & $p$ \\
\hline 1110001 & 161 & 113 & 71 & a \\
\hline 1110010 & 162 & 114 & 72 & \\
\hline 1110011 & 163 & 115 & 73 & $s$ \\
\hline 1110100 & 164 & 116 & 74 & t \\
\hline 1110101 & 165 & 117 & 75 & $u$ \\
\hline 1110110 & 166 & 118 & 76 & $\checkmark$ \\
\hline 1110111 & 167 & 119 & 77 & $w$ \\
\hline 1111000 & 170 & 120 & 78 & $x$ \\
\hline 1111001 & 171 & 121 & 79 & y \\
\hline 1111010 & 172 & 122 & $7 \mathrm{~A}$ & $z$ \\
\hline 1111011 & 173 & 123 & 78 & 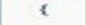 \\
\hline 1111100 & 174 & 124 & 70 & 1 \\
\hline 1111101 & 175 & 125 & 70 & 3 \\
\hline 1111110 & 176 & 126 & $7 E$ & $\sim$ \\
\hline
\end{tabular}

Gambar 2. Kode ASCII

Nilai Hexadecimal

: Kelompok A = 2B 27 28 2E 2A 212528

Kelompok B = 29 2727 2C 2B 262427

Kelompok C = 27 2B 2A 2D 2A 2E 2926 
Nilai Biner:

$A=0010101100100111001010000010111000101010001000010010010100101000$

$B=0010100100100111001001110010110000101011001001100010010000100111$

$\mathrm{C}=0010011100101011001010100010110100101010001011100010100100100110$

Proses pembangkitan kunci pada setiap fungsi pada algoritma Pisanc Cipher dilakukan berdasarkan karakter yang dimasukan oleh pengguna sebagai kata atau kalimat kunci. Sebagai contoh pembangkit kunci menggunakan karakter "FAJAR RIZKY". Adapun jumlah panjang kunci yaitu sebesar 64 bit, jika melebihi maka yang digunakan hanya 64 bit saja untuk bit selanjutnya tidak dianggap. Jika kurang dari 64 bit maka dilakukan penambahan bit nol hingga mencukupi jumlah 64 bit. Pada penelitian ini penulis menggunakan karater kunci yaitu:

Karakter

Nilai Hexadecimal

: FAJAR RIZKY

NilaiBiner

\section{: 46414 A 41522052495 A 4 B 59}

: 0100011001000001010010100100000101010010001100100101001001001001 010110100100101101011001

Dari nilai biner diatas maka biner yang digunakan hanya 64 bit yaitu : $\underline{0100011001000001010010100100000101010010001100100101001001001001}$

Selanjutnya melakukan proses encoding NRZI dengan cara jika biner kiri bernilai satu maka lakukan perubahan terhadap masing-masing biner disebelah kanannya, jika sebelah kiri bernilai nol maka lakukan perubahan terhadap biner setelah menemukan angkat satu disebelahkanannya, lebih jelasnya dapat dilihat pada gambar berikut ini

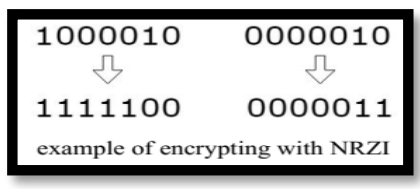

Gambar 3. Enkoding NRZI

Berikut hasil perubahan nilai blok biner sesuai dengan metode NRZI.

$A=0010101100100111001010000010111000101010001000010010010100101000$ Menjadi

0011010011011000110101111101000111010101110011101101101011010111

$B=0010100100100111001001110010110000101011001001100010010000100111$

Menjadi

0011011011011000110110001101001111010100110110011101101111011000

$\mathrm{C}=0010011100101011001010100010110100101010001011100010100100100110$

Menjadi

0011100011010100110101011101001011010101110100011101011011011001

Berdasarkan penerapan NRZI diatas maka didapatkan nilai biner Plainvoice, yang dimana nilai biner tersebut akan dilakukan ekstrasi lagi dengan triple feistel yang akan melakukan proses perputaran dengan dibagi tiga feistel setiap putaran. Putaran tersebut maka yang akan dihasilkan pengamanan hingga tingkat kebingungan dan difusi, adapun nilai dari proses NRZI tersebut yaitu sebagai berikut:

$A_{0}=0011010011011000110101111101000111010101110011101101101011010111$
$B_{0}=0011011011011000110110001101001111010100110110011101101111011000$
$C_{0}=0011100011010100110101011101001011010101110100011101011011011001$

Setelah dilakukan proses penerapan pada NRZI maka di dapatkanlah hasil binernya. Dimana nilai biner tersebut akan melakukan ekstrasi menggunakan teknik triple feistel yang memelakukan proses penerapannya dibagi menjadi tiga blok setiap putarannya. Dan putaran tersebut akan di XOR kan Maka selanjutnya akan dilakukan proses pemutaran nilai biner sampai $10 \mathrm{x}$ putaran. Adapun proses penerapannya sebagai berikut :

1. Putaran Pertama (1)

a. Mencari Nilai Kunci Function 1 (F $\left.\mathbf{F}_{1}\right)$ : Proses XOR biner "B," dengan biner "Kunci"

$\underline{\mathrm{B}}_{0} \oplus$ Kunci $=\mathrm{F} 1$

0011011011011000110110001101001111010100110110011101101111011000

$0100011001000001010010100100000101010010001100100101001001001001 \quad \oplus$

0111000010011001100100101001001010000110111010111000100110010001

b. Mencari Nilai Ao' dengan melakukan proses XOR biner "A," dengan biner "Function 1"

$\underline{\mathrm{A}}_{0} \oplus \mathrm{F}_{1}=\mathbf{A}_{0}$,

0011010011011000110101111101000111010101110011101101101011010111

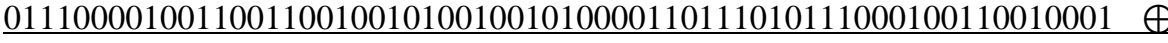

0100010001000001010001010100001101010011001001010101001101000110 
c. Mencari Nilai Kunci Function $2\left(\mathbf{F}_{2}\right)$ : Proses XOR biner "C $\mathrm{C}_{0}$ " dengan biner "Kunci"

$\underline{\mathrm{C}}_{0} \oplus$ Kunci $=\mathbf{F}_{2}$

0011100011010100110101011101001011010101110100011101011011011001 $0100011001000001010010100100000101010010001100100101001001001001 \oplus$

0111111010010101100111111001001110000111111000111000010010010000

d. Mencari Nilai Bo" dengan melakukan proses XOR biner " $\mathrm{B}_{0}$ " dengan biner "Function 2"

$\underline{\mathrm{B}}_{0} \oplus \oplus \mathrm{F}_{2}=\mathrm{B}_{0}{ }_{-}^{\prime}$

0011011011011000110110001101001111010100110110011101101111011000

$0111111010010101100111111001001110000111111000111000010010010000 \oplus$

010010000100110101000111010000000101001001110100101111101001000

e. Mencari Nilai $\mathbf{C}_{\mathbf{0}}$ ' masih bernilai sama dengan $\mathrm{C}_{0}$

$\mathrm{C}_{0}{ }^{\prime}=\mathrm{C}_{0}$

$\mathrm{C}_{0}{ }^{\prime}=0011100011010100110101011101001011010101110100011101011011$

f. Hasil Proses Putaran Pertama (1)

A0 ${ }^{\prime}=0100010001000001010001010100001101010011001001010101001101000110$

$\mathrm{B}^{\prime}=0100100001001101010001110100000001010011001110100101111101001000$

$\mathrm{C}^{\prime}{ }^{\prime}=0011100011010100110101011101001011010101110100011101011011011001$

2. Putaran Kedua (2)

a. Tentukan nilai $\mathbf{A}_{\mathbf{1}}, \mathbf{B}_{\mathbf{1}}, \mathbf{C}_{\mathbf{1}}$ dengan format sebagai berikut

$\mathrm{A} 0^{\prime}=\mathrm{B} 1$

$\mathrm{B} 0^{\prime}=\mathrm{C} 1$

$\mathrm{C} 0^{\prime}=\mathrm{A} 1$

Berdasarkan format diatas maka nilai A1, B1, C1, sebagai berikut:

$\mathrm{A} 1=0011100011010100110101011101001011010101110100011101011011011001$

$\mathrm{B} 1=0100010001000001010001010100001101010011001001010101001101000110$

$\mathrm{C} 1=0100100001001101010001110100000001010011001110100101111101001000$

b. Mencari Nilai Kunci Function $1\left(\mathbf{F}_{1}\right)$ : Proses XOR biner "B," dengan biner "Kunci"

$\underline{\mathrm{B}}_{1} \oplus \mathrm{K}=\mathbf{F}_{1}$

0100010001000001010001010100001101010011001001010101001101000110

$0100011001000001010010100100000101010010001100100101001001001001 \oplus$

0000001000000000000011110000001000000001000101110000000100001111

c. Mencari Nilai $\mathbf{A}_{\mathbf{1}}$ ' dengan melakukan proses XOR biner " $\mathrm{A}_{1}$ " dengan biner "Function 1"

$\underline{\mathrm{A}_{1}} \oplus \mathrm{F} 1$

0011100011010100110101011101001011010101110100011101011011011001

$0000001000000000000011110000001000000001000101110000000100001111 \oplus$

0001101011010100110110101101000011010100110001101101011111010110

d. Mencari Nilai Kunci Function $2\left(\mathbf{F}_{2}\right)$ : Proses XOR biner " $\mathrm{C}_{1}$ " dengan biner "Kunci"

$\underline{\mathrm{C}}_{1} \oplus \mathrm{K}=\mathbf{F}_{2}$

0100100001001101010001110100000001010011001110100101111101001000

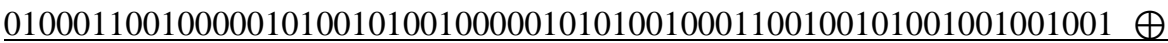

0000111000001100000011010000000100000001000010000000110100000001

e. Mencari Nilai $\mathbf{B}_{1}$ ' dengan melakukan proses XOR biner " $\mathrm{B}_{1}$ " dengan biner "Function 2"

$\underline{\mathrm{B}}_{1} \oplus \mathrm{F}_{2}=\mathbf{B}_{1}$,

0100010001000001010001010100001101010011001001010101001101000110

$0000111000001100000011010000000100000001000010000000110100000001 \oplus$

0100101001001101010010000100001101010010001011010101111001000111

f. Mencari Nilai $\mathbf{C}_{\mathbf{1}}$ ' masih bernilai sama dengan $\mathrm{C}_{1}$

$\mathrm{C}_{1}{ }^{\prime}=\mathrm{C}_{1}$

$\mathrm{C}_{1}{ }^{\prime}=0100100001001101010001110100000001010011001110100101111101001000$

g. Hasil Putaran Kedua (2)

$\mathrm{A}_{1}{ }^{\prime}=0001101011010100110110101101000011010100110001101101011111010110$

$\mathrm{B}_{1}{ }^{\prime}=0100101001001101010010000100001101010010001011010101111001000111$

$\mathrm{C}_{1}{ }^{\prime}=0100100001001101010001110100000001010011001110100101111101001000$

Lakukan proses tersebut berulang hingga pada proses ke - 10 (sepuluh). Dari proses XOR yang telah dilakukan sampai mencapai $10 \mathrm{x}$ putaran tersebut, Maka nilai yang dihasilkan oleh ciphervoice chat pada algoritma Pisanc adalah : 
Journal of Computer System and Informatics (JoSYC)

Volume 2, No. 4, August 2021, Page 288-294

ISSN 2714-8912 (media online)

ISSN 2714-7150 (media cetak)

DOI 10.47065/josyc.v2i4.819

Dari hasil XOR yang dilakukan, maka menghasilkan nilai Ciphervoice. Dan selanjutnya akan di rubah menjaadi nilai hexadesimal. Adapun nilai yang di hasilkan yaitu sebagai berikut:

\section{4D 4740 52 2A 4F 48 1B D4 DA Do D4 C6 D4 D6 4B 4D 4843 52 2D 5E 47}

\subsection{Proses Pengujian}

Proses pengujian dalam penelitian ini dilakukan terhadap beberapa file video yang berbeda, berikut tabel hasil pengujian yang telah dilakukan:

Tabel 1. Hasil Pengujian

\begin{tabular}{|c|c|c|c|c|c|}
\hline No. & $\begin{array}{c}\text { Spesifikasi File } \\
\text { Video Asli }\end{array}$ & $\begin{array}{l}\text { Kode Hash File } \\
\text { Video Asli }\end{array}$ & $\begin{array}{c}\text { Perubahan } \\
\text { yang } \\
\text { dilakukan }\end{array}$ & $\begin{array}{c}\text { Spesifikasi File } \\
\text { Video Palsu }\end{array}$ & $\begin{array}{c}\text { Kode Hash File } \\
\text { Video Asli }\end{array}$ \\
\hline 1 & $\begin{array}{l}\text { NamaFile: } \\
\text { ALDO } \\
\text { Ukuran: } 654 \mathrm{~Kb} \\
\text { Durasi: 01:00 } \\
\text { Jenis: *.mpg }\end{array}$ & $\begin{array}{l}\text { E4A40F15AE54AA } \\
\text { E07B72B2E0611AD } \\
\text { CFA }\end{array}$ & $\begin{array}{l}\text { Memotong } \\
\text { durasi video }\end{array}$ & $\begin{array}{l}\text { NamaFile: ALDO } \\
\text { Ukuran: } 580 \mathrm{~Kb} \\
\text { Durasi: 00:55 } \\
\text { Jenis: *.mpg }\end{array}$ & $\begin{array}{l}\text { A4E40F15AE54 } \\
\text { 2AE32B723450 } \\
\text { 611A5CCB }\end{array}$ \\
\hline 2. & $\begin{array}{l}\text { NamaFile: } \\
\text { aldo1 } \\
\text { Ukuran: } \\
693 \mathrm{~Kb} \\
\text { Durasi: 00:57 } \\
\text { Jenis: *.mpg }\end{array}$ & $\begin{array}{l}\text { 0C00D49F80EFA78 } \\
\text { 5DDCAD01A0FFFF } \\
700\end{array}$ & $\begin{array}{l}\text { Menambah } \\
\text { kontras video }\end{array}$ & $\begin{array}{l}\text { NamaFile: } \\
\text { aldo1 } \\
\text { Ukuran: } 720 \mathrm{~Kb} \\
\text { Durasi: 00:57 } \\
\text { Jenis: *.mpg }\end{array}$ & $\begin{array}{l}\text { BA2DDA481FD } \\
\text { D08EDDC8AF0 } \\
\text { EA00A1FCA7 }\end{array}$ \\
\hline 3. & $\begin{array}{l}\text { NamaFile: aldo2 } \\
\text { Ukuran: } 820 \mathrm{~Kb} \\
\text { Durasi: 01:20 } \\
\text { Jenis: *.mpg }\end{array}$ & $\begin{array}{l}\text { DD0AC7F9C00E1A } \\
\text { AF5CD4AE0DAC0 } \\
\text { ABB2E0 }\end{array}$ & $\begin{array}{l}\text { Menambah } \\
\text { watermark } \\
\text { didalam video }\end{array}$ & $\begin{array}{l}\text { NamaFile: aldo2 } \\
\text { Ukuran: } 898 \mathrm{~Kb} \\
\text { Durasi: 01:20 } \\
\text { Jenis: *.mpg }\end{array}$ & $\begin{array}{l}\text { 0C00D49F80EF } \\
\text { A785DDCAD01 } \\
\text { A0FFEE700 }\end{array}$ \\
\hline
\end{tabular}

\section{KESIMPULAN}

Dari hasil penelitian yang dilakukan penulis, maka dihasilkan suatu kesimpulan yang memberikan terobosan baru pada pengguna layanan pesan suara atau voice chat pada Whattshapp, yang dimana nantinya dapat memberikan kontribusi bagi kenyamanan pengguna layanan voice chat. adapun kesimpulan Teknik autentikasi voice chat merupakan teknik yang bertujuan untuk membutikan keaslian suatu pesan suara dengan merubah bilangan biner kedalam menjadi bentuk digital. Teknik algoritma Pisanc Cipher merupakan teknik yang digunakan untuk mengautentikasi voice chat yang menggabungkan antara NRZI dan triple feistel.

\section{REFERENCES}

[1] Usman, "https://www.pengertianmenurutparaahli.net/pengertian-implementasi/," Pengertian Implementasi menurut para ahli, 2002. [Online].

[2] D. N. Novi and E. W. Anang, "PENERAPAN TEKNIK KRIPTOGRAFI STEAM - CHIPER UNTUK PENGAMANAN BASIS DATA," Jurnal Basis Data, vol. Vol. 6, no. No.1, pp. 2-22, 201.

[3] L. Mokh. and A. Putra, "https://docplayer.info/50630911-Enkripsi-dan-dekripsi-pesan-suara-dengan-metode-algoritmaserpent-menggunakan-visual-basic-6-0.html," ENKRIPSI DAN DEKRIPSI PESAN SUARA DENGAN METODE ALGORITMA SERPENT MENGGUNAKAN VISUAL BASIC 6.0. [Online].

[4] P. Arif and N. Nurdin , "ANALISA DAN IMPLEMENTASI KRIPTOGRAFI PADA PESAN RAHASIA MENGGUNAKAN ALGORITMA CIPHER TRANSPOSITION," Jurnal Elektronik Sistem Informasi dan Komputer, vol. Vol.3, no. No.1, pp. 2-11, Januari-Juni 2017.

[5] F. Lazuadi, "http://informatika.stei.itb.ac.id," Kriptografi PISANC CHIPER, 05. 2018-2019. [Online]. [Accessed 012019/makalah1 Kriptografi-2019-05.].

[6] E. H. R. D. W. U. d. R. R. S. C. A. Sari, "Penyembunyian Data Untuk Seluruh Ekstansi File Mengguanakan Kriptografi Vernam Cipher dan Bit Shiffing," Journal of Applied Intelligent System, vol. vol.1, pp. 179-190, 2016.

[7] S. M. Melwin Syafrizal, "https://journal.amikom.ac.id/index.php/KIDA/article/download/4475/2170," journal.amikom.ac, pp. 2-13.

[8] s. Fharis, "http://harissitumeangdetektif.apa-itu-cipher-code.html," blogspot.com, 07 2013. [Online].

[9] jakfar, "https://www.scribd.com/document/389239727/Pengertian-Autentikasi," [Online].

[10] "https://www.maxmanroe.com/vid/teknologi/pengertian-chatting.html," Pengertian Chatting dan Contohnya, Fungsi, Serta Manfaatnya. [Online].

[11] S. N, "http://www.pengertianku.net/2015/02/pengertian-chatting-dan-fungsinya-secara-lebih-jelas.html," pengertianchatting-dan-fungsinya-secara-lebih-jelas., 02 2015. [Online].

[12] D. P. 2, "https://www.dosenpendidikan.com," pengertian-chatting-fungsi-manfaat-dampak/, 10022019.

[13] E. Sutanta, Pengantar Teknologi Informasi, Graha Ilmu., Yogyakarta, 2005. 
Journal of Computer System and Informatics (JoSYC)

Volume 2, No. 4, August 2021, Page 288-294

ISSN 2714-8912 (media online)

ISSN 2714-7150 (media cetak)

DOI 10.47065/josyc.v2i4.819

[14] K. L.V. , "Available:http://www.vbtutor.net/index.php/visual-basic-2010-tutorial/," Visual Basic 2010 Tutorial [online], 6 oktober 2012. [Online].

[15] HEADER AKIB, "Haedar Akib/ Jurnal Administrasi Publik," IMPLEMENTASI KEBIJAKAN:, vol. Volume 1, no. No. 1 , pp. 2-11, Thn. 2010. 